\title{
STRATEGIC ARCHITECTURE FOR TINPLATE INDUSTRY IN INDONESIA
}

\author{
Fahren Zulangga Utama*, Jahroh Siti, Saptono Imam Teguh \\ School of Business, Bogor Agricultural University, Indonesia \\ *E-mail: zulangga.fahren@gmail.com
}

\begin{abstract}
In the high level business of competition, a competitive advantage of company is only due to the influence of the dynamic environment and uncertainty. In order to have sustainable competitive advantage, a company must develop and strengthen their core competences to give value for customer. One of industry that is affected by disruption related to rapid business changing is tinplate industry. PT Latinusa Tbk that engaged in tinplate industry which is the only one in Indonesia conduct business transformation that focus on strengthening core competence for their existence in doing bussiness. This research aim to identify current core competence of PT Latinusa Tbk, to develop industry foresight base on core competence and to make architecture strategic towards new future industry. This research uses qualitative descriptive and quantitative method. Processing techniques and data analysis in this study is descriptive qualitative analysis that is VRIO Analysis to identify core competences of company, gap analysis to set strategic challenges, using the architecture strategy to set strategy toward industry foresight. The result of this research shows that the industry foresight of tinplate company with managing new core competence such as customer relationship management and supply chain management. The company's strategic architecture is arranged for the next 10 years that is divided into 3 strategic steps such as competence strengthening strategy, bussiness growing strategy and performance excellence strategy.
\end{abstract}

\section{KEY WORDS}

Core competence, strategic architecture, tinplate industry, business.

National strategic sectors, such as steel, are hot targets for companies outside Indonesia. The term that is popular today to describe the situation of a rapidly changing business environment is called the VUCA, which stands for volatility, uncertainty, complexity and ambiguity. Although the Steel Industry is an Expanding category if it is grouped according to the Mentality and Turbulence category by Igor Ansoff, it is possible to be affected by disruption innovation. It is not surprising to see the phenomenon of several steel industry in Indonesia experiencing a crisis and closing down. One of the steel derivative industries is the Tinplate Industry. PT Pelat Timah Nusantara, Tbk (Latinusa) with the largest market share in Indonesia must be able to compete with foreign competitors such as China, Korea, Japan, Malaysia and Germany. Latinusa was established on August 19, 1982 under the name PT Pelat Timah Nusantara (Latinusa) to carry out the vision of becoming the best integrated steel packaging company (tinplate) in the AFTA region through high quality production at competitive prices and timely delivery for customer satisfaction.

The company's core competency itself is a series of competencies owned by a company that is formed from the company's ability to manage its tangible and intangible assets (Wheelen and Hunger, 2012). Company competencies that are valuable to their customers and have advantages over competitors, and are rare and can be maintained or difficult to replicate, will form the basis for the formation of sustainable competitive advantage. Thus, it is important for Latinusa to know its core competencies and must continue to work towards developing these core competencies in the future. The conditions of the above problems create urgency for this research. Not only limited to knowing core competencies, but an overview of the industry is needed in the future (Industry Foresight), corporate challenges so that they can be formulated in the form of strategic architecture, high-level blueprints between current conditions and the future of Latinusa. 


\section{LITERATURE REVIEW}

Strategy management is a set of managerial decisions and actions to determine the company's performance in the long run (Hunger and Wheelen 2012). According to David (2009) strategy management is the art and knowledge of formulating, implementing and evaluating cross-functional decisions that make an organization able to achieve its objectives. Strategic architecture is a dynamic and flexible approach in making strategic planning to deal with rapid changes in the business environment. According to Hamel and Prahalad (1994), strategic architecture is a high-level blueprint in relation to new activities, mastery of new competencies, or development of existing competencies, and restructuring of organizational interactions with its customers in the future. Strategic architecture is different from strategic planning (strategic planning) with fundamental differences can be explained in the following Table 1 (Hamel and Prahalad 1994).

Table 1 - Differences in strategic planning and strategic architecture

\begin{tabular}{|c|c|c|}
\hline Aspect & Strategic Planning & Strategic Architecture \\
\hline Objective & Increased market share and company position & $\begin{array}{l}\text { Redesigning industry boundaries and } \\
\text { creating new areas of competition }\end{array}$ \\
\hline Process & $\begin{array}{l}\text { Formulations and routines } \\
\text { Current industry and market structure as a baseline } \\
\text { Using industry analysis (segmentation analysis, value } \\
\text { chain analysis, cost structure analysis, competitor } \\
\text { benchmarking) } \\
\text { Individual business as a unit of analysis }\end{array}$ & $\begin{array}{l}\text { Exploratory and open-ended } \\
\text { Discontinuous understanding and } \\
\text { competence as a baseline } \\
\text { Search for new functionality } \\
\text { Development of new competency } \\
\text { acquisition and migration plans } \\
\text { The corporation as a unit of analysis }\end{array}$ \\
\hline Resources & $\begin{array}{l}\text { Executive } \\
\text { Expert }\end{array}$ & $\begin{array}{l}\text { Manager } \\
\text { Company experience }\end{array}$ \\
\hline
\end{tabular}

Resource-based view or commonly known as RBV is an approach taken to achieve competitive advantage from an organization initiated by B. Wernerfelt, Prahalad and Hamel, J. Barney, and others between 1980 and 1990s. Proponents of this view believe that an organization must look into the company itself to find sources of competitive advantage rather than focusing on the competitive environment. RBV for competitive advantage shows that internal resources are more critical for a company than external factors in achieving and maintaining a competitive advantage. The RBV's view emphasizes that organizational performance will primarily be determined by internal resources that can be grouped into three categories that cover all: physical resources, human resources, and organizational resources. Physical resources include factories and equipment, location, technology, raw materials, machinery. Human resources include all employees, training, experience, intelligence, knowledge, skills, abilities; and organizational resources including company structures, planning processes, information systems, patents, trademarks, copyrights, databases, and so on. The RBV theory asserts that resources are the real ones that help companies take advantage of opportunities and neutralize threats (David, 2011)

According to Barney and William (2015), resources in the RBV are defined as tangible and intangible resources that are controlled by a company that can be used to understand and implement its strategy. Hitt et al. (2017) state that tangible resources are resources that can be observed and measured. Production equipment, manufacturing facilities, distribution centres, and formal reporting structures are examples of tangible resources. Intangible resources are resources that are deeply rooted in the history of the company, accumulated over time, and are relatively difficult for competitors to analyze and replicate. Because they are embedded in a unique pattern of routines, intangible resources are difficult for competitors to analyze and imitate. Knowledge, trust between managers and employees, managerial abilities, organizational routines (the unique way people work together), scientific capabilities, innovation capacity, brand names, company reputation from goods or services, and organizational culture are intangible resources. Capability is the ability of a company to exploit these resources. Capability consists of business processes and routine things that are done in managing interactions between resources that convert the input into the output. For 
example, marketing capabilities are interactions between marketing teams, distribution channels, and sales teams. Capability is functionally based and attached to specific functions. Thus, there are marketing capabilities, manufacturing capabilities, human resource management capabilities. When these capabilities continue to change and are configured to make them more adaptive to uncertain environments, they are referred to as dynamic capabilities (Schreyogg and Kliesch-Eberl, 2007).

Based on the resource-based view, the different core competencies derive the company's competitive advantage compared to its competitors. The company's core competency itself is a series of competencies owned by the company that is formed from the company's ability to manage both tangible and intangible resources. Core competency is a collection of competencies that cross divisional boundaries, are widespread within the corporation, and are something that the company can do in an excellent way (Wheelen and Hunger, 2012).

Barney, through the VRIO framework, proposes four questions to analyze and evaluate company competencies. The questions are:

- Value: Do a firm's resources and capabilities enable the firm to respond to environmental threats or opportunities?

- Rareness: Is a resource currently controlled by only a small number of competing firms?

- Imitability: Do firms without a resource face a cost disadvantage in obtaining or developing it?

- Organization: Are a firm's other policies and procedures organized to support the exploitation of its valuable, rare, and costly to imitate resources?

Resources and capabilities that meet the above questions which represent four criteria are valuable, rare (rare/unique), costly to imitate (expensive to imitate), and organization (organized) referred to as core competencies.

Table 2 - VRIO analysis is a resource or capability

\begin{tabular}{|c|c|c|c|c|c|}
\hline Valuable? & Rare? & $\begin{array}{l}\text { Costly to } \\
\text { imitate? }\end{array}$ & $\begin{array}{l}\text { Exploited by the } \\
\text { organization? }\end{array}$ & $\begin{array}{l}\text { Competitive } \\
\text { implication }\end{array}$ & Strength or Weakness \\
\hline No & - & - & No & $\begin{array}{l}\text { Competitive } \\
\text { disadvantage }\end{array}$ & Weakness \\
\hline Yes & No & - & No & Competitive parity & Strength \\
\hline Yes & Yes & No & No & $\begin{array}{l}\text { Temporary } \\
\text { competitive advantage }\end{array}$ & $\begin{array}{l}\text { Strength and distinctive } \\
\text { competence }\end{array}$ \\
\hline Yes & Yes & Yes & Yes & $\begin{array}{l}\text { Sustained competitive } \\
\text { advantage }\end{array}$ & $\begin{array}{l}\text { Strength and distinctive } \\
\text { sustainable competence }\end{array}$ \\
\hline
\end{tabular}

According to Hamel and Prahalad (1994), new industries can only be created through an ability to see far ahead, through imagination and predictions of what is called insight into future industrial scenarios. This not only requires management commitment to create new products, but rather leads to the formation of new competencies. Industry Foresight analysis is very helpful for management in identifying the following (Hamel and Prahalad 1994).

- New benefits that should be able to be offered to consumers in the future by utilizing current competencies;

- New competencies and functionalities that must be possessed by the organization in order to be able to provide added value to consumers;

- Configuration of markets and consumers that must be served in the future.

Corporate challenges become a major part of the structure in a way that connects today with the future (Hamel and Prahalad 1994). Hamel and Prahalad (1989) suggest that in order to be able to find the future, an organization is not enough to go through the learning process (learning), but also have to go through the process of forgetting and abandoning old habits and paradigms. To carry out the forgetfulness process, a strategic intent is needed, that is a dream or strategic desire that the organization really wants to achieve in the future. There are 3 criteria for setting strategic intent for a company, which are sense of direction, sense of discovery and sense of destiny. Sense of direction is a point of view about the 
company in the long run or the competitive position of the company that was built over the coming decade, the sense of discovery that is strategic intent requires a unique way of competing in the future that will force employees to go out and investigate competitive areas that are new, and sense of destiny where strategic intent has an emotional side.Corporate challenges become a major part of the structure in a way that connects today with the future (Hamel and Prahalad 1994).

\section{METHODS OF RESEARCH}

This research was conducted in March 2019 until July 2019. The research method used was descriptive qualitative research method. Geertz (1973) described the power of qualitative research as getting a "thick description" or better understanding the context of an issue. There are several reasons why this research uses qualitative design. First, the qualitative approach focuses on the importance of the individual in it. Second, the qualitative approach is very suitable in exploratory studies where little knowledge is there. Besides, a qualitative approach can provide a quick understanding to help decisions when time is a problem (MacDonald, 2007). The qualitative approach also provides a detailed description of the life experiences of study participants. The descriptive research method is aimed at describing the characteristics of an object of people, groups, organizations, and the environment. One simplified approach of this research is the survey approach (Sumarwan et al., 2018). Descriptive research methods are used to obtain an overview of information, explanations, and conditions relating to the object of research in factually accurate and systematic. This study uses respondents consisting of directors and managements (internal respondents), from PT Latinusa Tbk.

Table 3 - List of respondents

\begin{tabular}{ll}
\hline Code & Area of function \\
\hline Respondent 1 & CEO \\
Respondent 2 & Commercial Director \\
Respondent 3 & Operational Director \\
Respondent 4 & GM Commercial \\
Respondent 5 & GM Production \\
Respondent 6 & Head of Sales Marketing \\
Respondent 7 & Head of Sales Process \\
Respondent 8 & Head of Production \\
Respondent 9 & Head of Production Planning \\
Respondent 10 & Head of Quality Assurance \\
Respondent 11 & Head of Accounting \\
Respondent 12 & Head of Finance \\
Respondent 13 & Head of Human Capital Management \\
\hline
\end{tabular}

Data collection technique is using purposive sampling. This technique is done by selecting respondents based on specific criteria (Sumarwan et al., 2018). This study uses primary data collection techniques carried out by survey techniques, namely in-depth interviews with questionnaire guidelines. Also, secondary data collection was carried out to support research by collecting literature studies from textbooks, journals, results of previous research and company-owned documentation as well as publication data from related companies and institutions as well as internet search results relevant to research. Data collection is done by using several techniques, namely:

- To identify the company's core competencies is done by distributing questionnaires with respondents selected through the judgment expertise approach, namely 3 directors and 10 management leaders;

- Focus Group Discussion (FGD), conducted with 3 Directors and management who are responsible for preparing the company's long-term plans, formulating the company's strategic challenges, identifying core competencies that must be developed or acquired in the future and an overview of products / services the company can provide; 
- The method of observation is by collecting data through direct observation at the research location (on the spot) to identify the competencies of the company;

- Literature study is obtained and collected by studying and quoting opinions from various book sources, theses, company management reports, studies from industry associations or documents.

In this research, the resources and capabilities chosen to be analyzed with VRIO analysis are those who have high levels of competence (4) and very high (5) to represent the resources and capabilities of the company because it shows an essential contribution to the company. The higher the number for one competency, the more critical it is for PT Latinusa Tbk. The technique for knowing core competencies is by using VRIO analysis (Valuable, Rare, Inimitability, Organizational). This method starts with placing tangible, intangible resources, and capabilities as inputs. Then select whether the resources and capabilities possessed provide value for customers (valuable), are rarely owned by other companies (rare), are not easily imitated (inimitability), and companies organize these competencies (organizational) (Barney and William, 2015). After obtaining the conclusions of core competencies from the two perceptions of management and directors, competency trees can be formed to describe the structure and flow of competencies that form PT Latinusa Tbk competitive advantages.

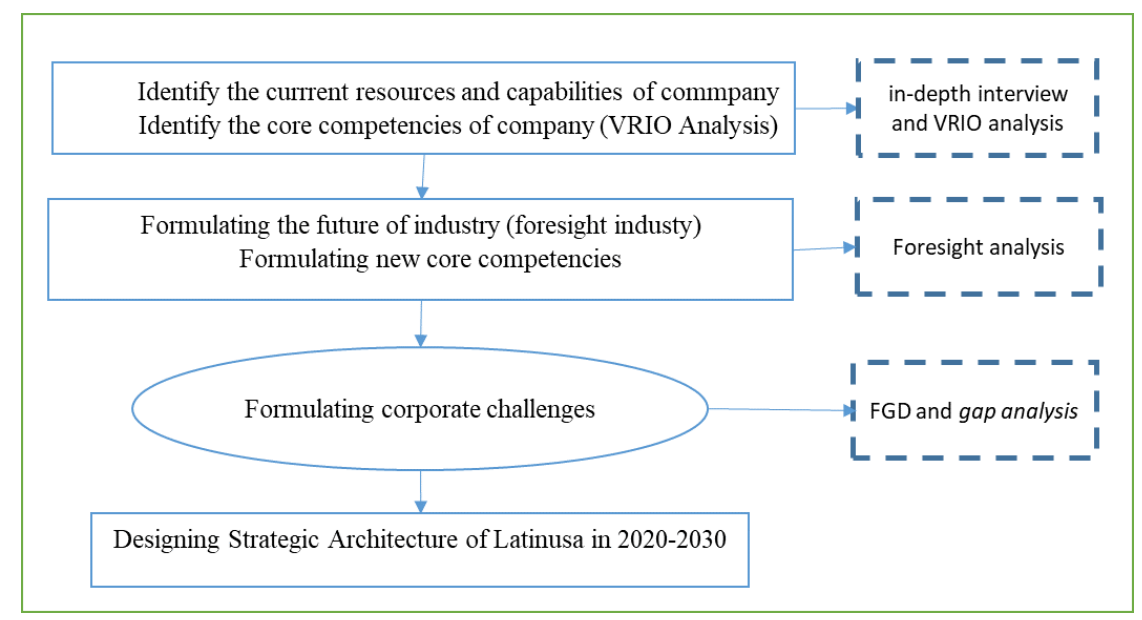

Figure 1 - Research framework and research steps

From the data and information collected, then the data is processed and then analyzed to get a picture of the company's strategic architecture. As figure 1, the research framework and research steps will be as below.

The initial step is to identify the company's resources and capabilities by conducting indepth interviews with directors and management. Then asking management to mention the current resources and capabilities of PT Latinusa Tbk. Once mentioned, management and directors are asked to rate these resources and capabilities using a Likert scale. Likert scale is used to measure attitudes, opinions, perceptions of a person or group of people about social phenomena. In this study, the Likert scale is used to measure the level of importance of resources and capabilities owned by PT Latinusa Tbk. The Likert scale used consisted of (1) very low, (2) low, (3) moderate, (4) high and (5) very high. The greater the number for one competency, the more important it is for PT Latinusa Tbk. In this study the resources and capabilities chosen for analysis with VRIO are those that have a high level of competence (4) and very high (5) to represent the company's resources and capabilities because they show an important contribution to the company. The higher the number for one competency, the more critical it is for Latinusa. The technique for knowing core competencies is by using VRIO analysis (Valuable, Rare, Inimitability, Organizational). This method starts with placing tangible, intangible resources, and capabilities as inputs. Then select whether the resources and capabilities possessed provide value for customers (valuable), are rarely owned by other companies (rare), are not easily imitated (inimitability), and companies organize these 
competencies (organizational) (Barney and William, 2015). After obtaining the conclusions of core competencies from the two perceptions of management and directors, competency trees can be formed to describe the structure and flow of competencies that form Latinusa competitive advantages.

Formulating the Industry of the Future (Industry Foresight). Management was interviewed through depth interview with those 3 main topics suc us:

- New benefits that should be able to be offered to consumers in the future by utilizing current competencies;

- New competencies and functionalities that must be possessed by the organization in order to be able to provide added value to consumers;

- Configuration of markets and consumers that must be served in the future.

To realize the company's new vision and mission, milestones must be achieved in the next 10 years by setting strategic challenges. Strategic challenges are a tool to arrange the stages in order to develop existing acquisitions and also acquire new competencies. The formulation of the company's strategic challenges is obtained from the gap analysis that compares the current condition of the company with the current condition of the business environment which is obtained from the results of discussions with 3 Directors.

Based on the formulation of industry foresight, strategic challenges, new vision and mission of the company, a long-term blueprint for developing strategic challenges in the context of realizing new industries and new company visions within the next 10 years. The formulation of strategies to be carried out in the company's strategic architecture design was obtained from FGD discussions with 3 Directors and 1 manager responsible for preparing the company's long-term plans enriched with various literature studies.

\section{RESULTS AND DISCUSSION}

Latinusa was established on August 19, 1982 under the name PT Pelat Timah Nusantara (Latinusa) to carry out the vision of becoming the best integrated steel packaging company (tinplate) in the AFTA region through high quality production at competitive prices and timely delivery for customer satisfaction. Simultaneously with the listing of shares, the majority ownership of Latinusa was transferred to $55.00 \%$ in the Japanese consortium. In addition to the Japanese consortium, the composition of the Company's share ownership at the end of 2018 consists of National Government. owns $20.10 \%$ of shares, private of $9.39 \%$, and the remaining $15.51 \%$ is held by the public with ownership less than $5.00 \%$.

The next step of research is to identify what resources and capabilities possessed by PT Latinusa Tbk. The thing to do is ask the respondent to mention what resources and capabilities the company currently has based on their perception. Then respondents were asked to give a score using a Likert scale to measure the level of competence of these resources and capabilities. The Likert scale used consisted of (1) very low, (2) low, (3) moderate, (4) high and (5) very high. The greater the scale of the competency scale, the higher the level of competence and more important for the company. In this study the resources and capabilities chosen are those that have a high level of competence (4) and very high (5) to represent the company's resources and capabilities because they show an important contribution to the company. At this stage, in-depth interviews are conducted faceto-face using questionnaire guidelines. The respondents interviewed were 10 people from management at the general manager and division heads. Two people are general manager of production and commercial and eight of them are division heads who represent important divisions in the company. In addition to getting a comparison of perceptions in identifying resources and capabilities, interviews were also conducted with 3 board of directors (Managing Director, Production Director and Commercial Director). The results of this indepth interview gave rise to 63 resources and capabilities based on respondents' perceptions but those with high levels of competency (4) and very high levels (5) only amounted to 52 resources and capabilities. Then the classification by type is done to facilitate the formulation of resources and capabilities. The result is 4 tangible resources, 7 intangible resources and 4 capabilities. The next stage in this research is to analyze the core competencies using VRIO 
analysis to obtain resources and capabilities that are sustained competitive advantage or have sustainable competitive advantages which are the company's core competencies. Based on the results of in-depth interviews with management respondents at the level of general manager and division head of PT LatinusaTbk, they do not have core competencies sourced from tangible resources. Core competencies sourced from intangible resources are reputation, customer relations, government relations, and collaboration. Whereas the core competencies sourced from capabilities are customer service, HR management, and production management. A summary of these core competencies can be seen in Table 4 .

Table 4 - Core competencies of PT Latinusa Tbk based on management perception

\begin{tabular}{llll}
\hline No. & Rescources and capabilities description & Category & Frequency \\
\hline 1 & Reputation & Intangible & 7 \\
2 & Customer relations & Intangible & 6 \\
3 & Government relations & Intangible & 3 \\
4 & Collaboration & Intangible & 2 \\
5 & Customer service & Capability & 2 \\
6 & HR management & Capability & 1 \\
7 & Production management & Capability & 1 \\
\hline
\end{tabular}

From 13 resources and capabilities based on management perspective, after VRIO analysis it was found that only 7 core competencies became sustained competitive advantage. These competencies include reputation, customer relations, customer service, government relations, collaboration, HR management and production management. If seen from Table 4, PT Latinusa Tbk's core competence from management's perception is dominated by intangible resources, with the most nomination is reputation. This reputation is influenced by the existence of PT Latinusa Tbk as the only tinplate producer in Indonesia. So that customers of PT Latinusa have long known and established business relationships with PT Latinusa Tbk. With almost thirty years of experience in the tinplate production process, it has made a reputation in the eyes of both customers and competitors. The reputation of being a single player who survives and who is still focused in this business is considered very difficult to be imitated by competitors. With a solid and strong organizational structure, effective SOPs in the work system in the field of tinplate make reputation a category of sustainable competitive advantage. The customer relationship is more described by customer flexibility, the majority of customers at PT Latinusa Tbk always conduct transactions with PT Latinusa Tbk routinely with a monthly frequency. Although foreign competitors are very easy to access customers, customers choose PT Latinusa Tbk as an average portion of more than sixty percent of the average market share of PT Latinusa Tbk customers. For some old customers from the beginning, PT Latinusa Tbk stood, choosing to give one hundred percent of their purchases to PT Latinusa Tbk. Customer relations are always maintained in the form of smooth communication from the position of ordinary staff to the position of customer directors, employees of PT Latinusa are very familiar with the customer organizational structure. Communication is not only in formal activities at the office but also can be outside the office for example by doing sports activities together. Government relations are also well established due to the regular meeting of the PT Latinusa Tbk team with the ministry team because historically this company was once a BUMN. After turning into a public company with a portion of PT Krakatau Steek Tbk shares of only $20 \%$ but the relationship with the government is still very close. This is due to the team of PT Latinusa Tbk still coordinating regularly with the Ministry of Industry and the Ministry of Trade. This core competency becomes a sustainable competitive advantage due to the difficulty of competitors having direct access to government. The collaboration competencies of PT Latinusa Tbk include the working relationship of PT Latinusa Tbk with its parent company and Japanese consortium. PT Latinusa Tbk shares owned by the Japanese consortium as much as $55 \%$ consists of several Japanese companies such as Nippon Steel, Mitsui, Sumitomo and Metal one. As a result, PT Latinusa Tbk collaborated with other important strategic positions in PT Latinusa Tbk with each consortium representative. Collaboration between companies is a strong competence of PT Latinusa Tbk in conducting 
steel business in Indonesia. Collaboration between companies provides a fundamental foothold in strategy and decision. Collaboration between parent companies with Japanese culture and local culture makes good collaboration in terms of cooperation in the supply of raw materials based on sustainable allocation. So that collaboration competence becomes a sustainable competitive advantage. Customer service is one of the company's KPIs, because it is included in the QCDD (Quality, Cost, Delivery, Development) strategy. Customer service must be measured in performance on the QCDD strategy. For example, in terms of quality, settlement of claims does not exceed 14 days, pricing must be competitive in line with market prices, delivery of materials for the farthest route takes no more than four days, as well as assistance in the development of customer product innovations. The focus on the QCDD system fills in depth organized to exploit aspects of VRIO analysis. Because the QCDD system has been tested every year in the form of SOPs which are increasingly effective and efficient. HR management and production management become core competencies that are sustainable competitive advantage when both management are not only difficult to imitate, but are also rooted in the foundation of an enterprise information system that is efficiently packaged with SAP and ESS. Connecting all employee needs in the field of human capital and business processes across divisions.

Based on the results of in-depth interviews with management respondents at the directors level, PT LatinusaTbk does not have core competencies sourced from tangible resources. Core competencies sourced from intangible resources are reputation, customer relations, government relations, and collaboration. Whereas core competency sourced by capability is only customer service. Summary for core competencies by director perception could be seen on Table 5 .

Table 5 - Core competencies of PT Latinusa Tbk based on director perceptions

\begin{tabular}{llll}
\hline No. & Resources and capabilities description & Category & Frequency \\
\hline 1 & Customer services & Capability & 4 \\
2 & Customer relations & Intangible & 3 \\
3 & Collaborations & Intangible & 3 \\
4 & Reputation & Intangible & 3 \\
5 & Government relations & Intangible & 2 \\
\hline
\end{tabular}

If seen from Table 5, PT Latinusa Tbk's core competence from the perception of directors is dominated by customer service capabilities, this provides a different perspective from the directors regarding PT Latinusa's value in providing services to customers. At PT Latinusa Tbk there is a QCDD value in the process of serving customers. QCDD itself consists of Quality, Cost, Development, Delivery. The QCDD strategy is controlled by KPIs in each division. Each directorate is responsible and has a role in this QCDD strategy because the work functions of each directorate are assigned to each relevant division. In accordance with the mission of PT Latinusa Tbk, namely to provide competitive prices and deliver on time. So from the directors' perception it was explained that the KPI system was very focused on focusing on customer service. So when analyzed using VRIO analysis customer service comes out as a sustainable competitive advantage. Customer relations are not only fostered by the sales team and technical team of PT Latinusa Tbk with customers, but here also the directors have regular meetings between the directors of customers and PT Latinusa Tbk. This meeting is called a periodical meeting where major issues related to business relations. The meeting period between customer and internal directors occurs in the quarter or semester cycle. Because of this program the meeting made close customer relations a core competency of PT Latinusa Tbk according to the directors' perception. Collaboration between stakeholders from the Japanese consortium is the strength of PT Latinusa Tbk. A routine program of directors' meetings with parent company directors at the head office in Tokyo, Japan to review Latinusa's business performance every year. The consortium will provide input and assistance with financial and commercial policies. With this routine program, the work objectives of PT Latinusa Tbk's RKAP will be easier to achieve. Insight from outside is very effective to provide solutions in solving company problems. So that the results of the 
VRIO analysis of the directors establish collaboration as core competencies with the category of sustainable competitive advantage. Reputation also comes out as the core competency that is sustainable competitive advantage after passing the VRIO analysis by the directors. In this case the perception obtained is more focused on the existence of PT Latinusa Tbk, which has been dealing with the Indonesian tinplate market for almost thirty years. Government relations become the core competency that is sustainable competitive advantage according to the directors. This is due to the involvement of government representatives in the organizational structure of the board of commissioners of PT Latinusa Tbk, this is very difficult to be imitated by competitors of PT Latinusa Tbk, all of which are foreign companies that are abroad.

Table 6 - Comparison of core competencies by Management and Director's perceptions

\begin{tabular}{ll}
\hline Core competencies by Management & Core competencies by Director \\
\hline Intangible resources & \\
\hline Customer relations & Customer relations \\
Collaborations & Collaborations \\
Reputation & Reputation \\
Government relations & Government relations \\
\hline Capabilities & \\
\hline Customer services & Pelayanan Pelanggan \\
& Manajemen SDM \\
\hline
\end{tabular}

It can be analyzed from Table 6 that there is a sliced perception between management and directors. So it can be concluded that the company's strength and unique competence compared to its competitors that brought PT Latinusa Tbk to compete competitively against competitors with a focus on the five core competencies that were included in customer relations, collaboration, reputation, government relations and customer service. For HR management and production management even though it is included in the category of core competencies with sustainable competitive advantages does not overlap with the directors' perceptions in the VRIO analysis. In addition, the frequency represented by only one part of management is not considered to be representative of the company's core competencies. The five competencies have been verified by the directors and management with the VRIO analysis validation process to become the five core competencies of PT Latinusa Tbk.

After finding the core competencies, the next stage is find out the future industry through industry Foresight. The main purpose of looking for a picture of the future of the industry is to make the best possible assumptions of the future related to industrial evolution. Industry Foresight Analysis is very helpful for management in identifying the following things according to (Hamel and Prahalad 1994) there are three important steps. The first step is to look for new benefits that should be able to be offered to consumers in the future. In the era of technological disruption today there is the term evolving customer demands. If you see in a year what is needed by customers may be likely to be the same. In the condition of PT Latinusa Tbk good customer relations makes issues related to changes and customer development plans can be known. But when discussing with the directors it is questionable how far PT Latinusa Tbk can see the evolutionary direction of change needed by the customer. The latest case experienced by PT Latinusa is one of PT Latinusa Tbk's customers in the milk segment with sweetened condensed milk products. When viewed five years back, sweetened condensed milk was only in the form of one product variant, but it changed by adding the EOE (Easy Open End) feature. For the development of this EOE, it still uses tinplate material and still uses PT Latinusa Tbk. However, a few years later there was a new line product at the customer, which is a type of sweetened thick pouch, which clearly did not use tinplate material but rather plastic material, within 2 years there was a change in the product of one of the customers of PT Latinusa Tbk. This change in product evolution for customers is an important information which is the planning of the customer research and development division. In the future era PT Latinusa Tbk must be able to see opportunities early by exploring customers' internal plans more deeply. So that PT Latinusa 
can anticipate faster with careful planning. More able to prepare a strategy what should be prepared and offered to customers. Besides the case of sweetened condensed milk, another segment is biscuits. Currently, customers of PT Latinusa Tbk get the supply of tinplate products in the form of coil and sheet. After receiving the coil product, the customer cuts the coil by cutting it into a tinplate sheet. Then the customer does the printing process and after that forms into a biscuit can. The future of customers will tend to be able to cut their supply chains by directly needing the final product they want to process, in which case they may want to buy printed sheets or buy cans directly. The second step is to find what core competencies are needed in the future, then what functionality the company must have as added value for customers. After being discussed with the directors, then the future needs of the trend is the need to point to the last supply chain that customers need. If the customer already has a printing machine, then the customer only needs a tinplate. But if the customer will eliminate the printing line to carry out their supply chain efficiency then they will buy the finished printed sheet. Meanwhile, if customers want to focus on fillers, customers will buy tinplate cans and their forming lines will disappear. In this case, customer relationship management expertise is needed to be more able to explore how long-term customer plans are, what are the strategic issues in customers related to demand in the market. In addition to customer relationship management, the process flow of tinplate into tiplate can through a long supply chain in this case required supply chain management competence. The third step is to look for market and consumer configurations that must be served in the future. Current customers of PT Latinusa only purchase tinplate coil and sheet products. To be competent in the future, PT Latinusa Tbk must be able to go to the myopia zone which is not yet available and has not been articulated properly by customer demand. Because to win the market in the future is one who can get opportunity share compared to market share. The myopia zone of PT Latinusa Tbk's products are tinplate tooling service product, which is a tooling service provider for tinplate derivative products according to customer needs. For example, PT Latinusa Tbk provides printed sheet and ready tinplate can products. In addition to diversifying future market configuration products, it is a supply chain system with real time data that is connected between PT Latinusa Tbk's data system and customer data systems.

Some of the competencies that must be developed by PT Latinusa Tbk to become the company's core competencies going forward include:

- Customer relationship management competence, namely the ability to manage relationships with customers using data and information that has been analyzed such as consumer behavior (customer behavior) as a source of information to improve service quality. In the tinplate industry whose products are manufacturing based, product innovation is the key word so that consumers can feel the sensation of new services. For this reason, consumer behavior using company services must be learned so that the services provided are always up to date. PT Latinusa Tbk must be sensitive to the slightest change in customers. Customer Relationship Management is not just high-tech enough, but must build a strong service foundation in the company's internal and external. A service foundation that is focused on efforts to win the hearts and minds of customers by being kind, in the form of services that provide all the conveniences so that all the wishes and expectations of customers are realized professionally. So when customers want to evolve product changes, PT Latinusa Tbk can be ready to assist the process of change and product development. Customer Relationship Management will become an important competency as the most important foundation for building the strength of PT Latinusa Tbk in the era of disruption and high turbulence in the future in an effort to provide excellent service in internal management and customers, including for all other stakeholders.

- Supply chain management competencies in the tinplate industry, its main activity is converting basic tinplate products such as coil and becoming tinplate with added values such as ptinted sheets and tinplate cans and distributing them to customers. But for a manufacturing company, this supply chain activity needs to be carried out effectively and efficiently so that professional management is needed in its implementation. In this case the most important supply chain portion is how to 
coordinate with the outsourcing party as a provider of printing and can making services. In addition to this competency needed a good supporting system to monitor the flow of stock from PT Latinusa Tbk to the partners and outsourcing to stock in the customer's warehouse. All data tracking is done in real time.

Table 7 - Future core competencies of PT Latinusa Tbk

\begin{tabular}{|c|c|c|c|}
\hline Industry Foresight & Parameter & Capability gap & Future Competence \\
\hline Capability - Driven Strategy & $\begin{array}{l}\text { How Latinusa can face the } \\
\text { market in future }\end{array}$ & $\begin{array}{l}\text { Latinusa has not give } \\
\text { maximum value through } \\
\text { added value category. }\end{array}$ & $\begin{array}{l}\text { Customer relationship } \\
\text { management }\end{array}$ \\
\hline Capability system & $\begin{array}{l}\text { How Latinusa can give the } \\
\text { competitive advantage to } \\
\text { customer in form of system } \\
\text { or tools. }\end{array}$ & $\begin{array}{l}\text { Latinusa has not run the } \\
\text { real time system of supply } \\
\text { chain }\end{array}$ & $\begin{array}{l}\text { Supply chain } \\
\text { management }\end{array}$ \\
\hline Product and service fit & $\begin{array}{l}\text { What and who Latinusa will } \\
\text { deal selling the product } \\
\text { based on what customer } \\
\text { need }\end{array}$ & $\begin{array}{l}\text { Latinusa does not have } \\
\text { additional services like } \\
\text { tooling services. }\end{array}$ & $\begin{array}{l}\text { Supply chain } \\
\text { management }\end{array}$ \\
\hline
\end{tabular}

Corporate Strategic Challenges (Corporate Challenges) from the results of interviews with the Directors of PT Latinusa Tbk can be identified that there are 4 key success factors that can be referred to as the company's strategic challenges in carrying out business transformation towards the tinplate industry and tolling provider consisting of:

1. The process of making a new business unit. For more than thirty years the tinplate industry in Indonesia has only been known as a provider of tinplate products with two types of products namely sheet and coil. During this time, customers of PT Latinusa Tbk carry out additional processes of printing and can making internally or in collaboration with vendor outsourcing. When PT Latinusa Tbk moves towards providing new products, PT Latinusa Tbk's business portfolio will be split into a new business unit that focuses on selling tinplate with additional services as a tooling provider. In this process will have an impact on the new organizational structure and in-depth research related to this new business unit in detail from the commercial side to the technical side. So we need a strategy to equip the character of "customer centric innovation" which is oriented to what is needed by the customer;

2. The partnership process with vendor tooling. In this new business unit the directors agreed not to make internal investments in printing process technology and can making processes. The fundamental reason that PT Latinusa Tbk is looking for partners is because of the substantial investment in the printing process technology and the can making process. The second fundamental reason is the number of vendors or suppliers that are available and have good relations with PT Latinusa Tbk. So it remains to be ascertained the process of selecting vendor partnerships must be done selectively because there are external stakeholders in the business flow of PT Latinusa Tbk;

3. Mastery of information systems in supporting the core process business units. In the manufacturing industry the ease and speed of services and lower prices in business processes requires technological innovation that is able to realize this (Lemy, 2010). Technology that can be utilized to enrich service features in the company's business units follows developments in the digital age such as ERP technology. In this case PT Latinusa already has an SAP system so that all that remains is to add the stock condition tracking system feature to third parties who are partners of PT Latinusa Tbk. According to the directors of PT Latinusa Tbk at present conditions, the business processes of PT Latinusa Tbk are still technologically minimal. So it needs to be prepared with a fast and real time information system.

After getting a picture of the company's future industry with a variety of core competencies needed and strategic challenges that must be achieved, the next step is to develop a strategic architecture design of the company in the next 10 years. From the results of the FGD with 3 Directors that the drafted strategy was aimed at achieving the direction of 
PT Latinusa Tbk as a provider of tinplate and tooling services in the AFTA region in the next 10 years. Broadly speaking, the corporate strategy is to create new process units that not only provide tinplate but also derived products such as printed sheets and tinplate cans.

For this reason, the architectural design is divided into 3 stages (milestone), namely stage 1 of competency strengthening stage through 2 main strategies, namely the strategy of creating the company's character as "Customer Centric Innovation" and the strategy of forming new business units, stage 2 of business growth (bussiness growing stage) through 2 main strategies namely increasing market share and becoming the "supply chain expert" stage 3 of improving company performance (performance excellence stage) through 2 main strategies namely a strategy of improving service quality and a cost leadership strategy. The detailed explanation of each stage of the strategy is outlined in the strategic architecture image of PT Latinusa Tbk as shown in Figure 2.

\begin{tabular}{|c|c|c|c|c|c|c|c|c|}
\hline \multicolumn{9}{|c|}{ Vision: The Best Tinplate and Tooling Provider Company in the AFTA Region } \\
\hline \multicolumn{9}{|c|}{ Corporate Challenge } \\
\hline \multirow[b]{3}{*}{ ్ㅗㅇ } & New business unit & $\begin{array}{l}\text { Tooling partnership } \\
\text { provider }\end{array}$ & $\begin{array}{r}\text { Inform } \\
\text { syste }\end{array}$ & & $\begin{array}{l}\text { World class } \\
\text { service }\end{array}$ & & npetitive advantage & \\
\hline & \multicolumn{2}{|c|}{ Strengthening Stage } & \multicolumn{3}{|c|}{ Bussiness Growing Stage } & \multicolumn{2}{|c|}{$\begin{array}{l}\text { Performance Excellence } \\
\text { Stage }\end{array}$} & \\
\hline & \multicolumn{2}{|c|}{$\begin{array}{c}2020-2021 \\
(2 \text { years) }\end{array}$} & \multicolumn{3}{|c|}{$\begin{array}{c}2022-2027 \\
\text { (5 years) }\end{array}$} & \multicolumn{2}{|r|}{$\begin{array}{c}2027-2030 \\
(3 \text { years })\end{array}$} & 芦 \\
\hline 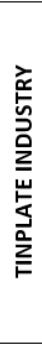 & \multicolumn{2}{|c|}{$\begin{array}{l}\text { - Customer centric innovation } \\
\text { - Customer insight and segemntation } \\
\text { - Creating information systems for supporting data real } \\
\text { - } \quad \text { Cooperation contracts with experienced } \\
\text { - Established a customer behavior training center and } \\
\text { - Chapply chain } \\
\text { - Changes in organizational structure. }\end{array}$} & \multicolumn{3}{|c|}{$\begin{array}{l}\text { - Market development by } \\
\text { increasing production capacity } \\
\text { - Strategy to strengthen national } \\
\text { market share to be } 80 \% \text { of } \\
\text { national tinplate consumption } \\
\text { - Supply chain expert. }\end{array}$} & \multicolumn{2}{|c|}{ 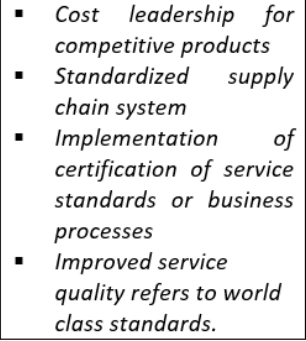 } & 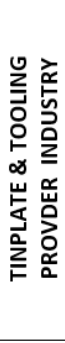 \\
\hline \multicolumn{4}{|c|}{ current competencies } & \multicolumn{5}{|c|}{ New future core competencies } \\
\hline \multicolumn{4}{|c|}{$\begin{array}{c}\text { Customer relation, collaboration, reputation, government relation, customer } \\
\text { service }\end{array}$} & \multicolumn{3}{|c|}{ Supply Chain Management } & \multicolumn{2}{|c|}{$\begin{array}{l}\text { Customer Relationship } \\
\text { Management }\end{array}$} \\
\hline
\end{tabular}

Figure 2 - Architecture Strateguc PT Latinusa Tbk

Competency strengthening stage: in this stage the strategy carried out aims to develop existing competencies and acquire new core competencies some of the strategies that can be carried out are as follows. First is customer centric innovation is the theme of strategy to create value at PT Latinusa Tbk for the time to make changes and innovations. For more than 30 years PT Latinusa Tbk has focused on one business unit while disruption in the tinplate business has increasingly experienced turbulence. Strategy in shaping the future is better than joining the flow of business turbulence (Prahalad 1994). This new business unit will change the organizational structure with the addition of 2 divisions in the commercial directorate namely new sales, market research division and tinplate tooling division. The addition of 1 division in the operational directorate is the QA printing and can making division. Second is to strengthen the competency of customer relationship management, a basic stage that will be applied at PT Latinusa Tbk is to get customer insight and segementation, this must be stated in the business map. and market requirements specifically according to customer requirements. Third is to form an HR that has the character of customer centric innovation, by strengthening the competence of customer relationship management and supply chain management, the strategy taken is to build a training center (learning center) in collaboration with educational institutions experienced in marketing, customer behavior, printing sheets and can making In addition, the strategy taken is to recruit experts at managerial level who are experienced in the printing, can making industries such as GM marketing and GM production.

Fourth is making cooperation contracts with vendors / suppliers / outsourcing that are trusted and have global standards so that the results of these products can represent the image of PT Latinusa Tbk with good quality assurance. Last is making additional features in 
the system that can monitor tinplate supply chains to additional processes such as printed sheets and tinplate cans from the finished process, delivery to customer stock. The system is made in real time conditions.

Business growth stage (bussiness growing stage): in this stage the strategy undertaken to increase market growth of the products and services produced by the company is an intensive strategy. The intensive strategy consists of 4 parts namely market development, product development, market penetration and innovation (Ansoff 1990). The strategy that will be used in this stage by taking into account the potential growth in demand for tinplate products and their derivatives, the level of competition which is also higher, especially imported products related to the condition of the free trade zone. Then the results of discussions with business unit leaders agreed to focus on two strategies, namely market development strategies and product development, consisting of market development strategy, through an investment strategy to increase the production capacity of the previous 160,000 MT tinplates per year to 180,000 MT per year. Strategy to strengthen the national market share target to $80 \%$ of national consumption in Indonesia. At this stage it is targeted to become a supply chain expert. With the foundation of supply chain management and the running of business units and real time tracking systems, PT Latinusa Tbk is targeted to the supply chain expert phase

Performance improvement stage: this stage is the final stage in the strategy architecture strategy. This stage of performance improvement consists of several strategies including Utilization of $100 \%$ production capacity with the basic goal of being cost leadership. So that they can offer the lowest prices to customers. Next is Standardization of supply chain systems. good infrastructure and facilities will not mean anything if the services provided do not satisfy consumers. For this reason, at this stage, the strategy adopted is to improve the quality of services to meet industry standards. The strategy that can be done is to certify the business processes of all service products from national and international certification bodies. Last is strategies for finding new competencies for the next ten years.

After all stages of the strategic architecture process from the start of core competencies, future formulations, strategic challenges and action plan strategies are formed in a strategic architectural container, the authors try to find validation from the results of this study of the literature and research that examines the same strategy to be taken by PT Latinusa Tbk. Wise and Baumgartner (1999) who created the theoretical model of manufacturing downstream strategy stated that manufacturing companies are very knowledgeable about their products and their markets in depth, so they can develop opportunities to reach downstream areas of their products. This strategy has proven to be very successful by implementing distribution channels, focusing on identifying new supply chain channels and being willing to take all the risk of conflict to gain competitive advantage. Take the case of Boeing which used to only focus on assembling and selling aircraft and then chose a downstream strategy by changing the supply chain path down to its downstream customers. Boeing sees the customer perspective more deeply so that it can be easier to apply complex downstream supply chains. So Boeing is currently taking the deepest supply chain by selling aircraft complete with catering service packages, parts-depot operations, refurbishment and resale.

\section{CONCLUSION}

Based on the results of the study in accordance with the objectives of the study, it can be concluded that based on the identification of company competencies using the VRIO Analysis approach, the company's core competencies are currently obtained in the form of customer relations, collaboration, reputation, government relations and customer service. The company's business transformation strategy is to change its industry from the tinplay industry to the inplate and tooling provider industry as a future industry. The new core competencies that must be mastered in the new industry are customer relationship management and supply chain management. A new business unit was formed at PT Latinusa Tbk, namely tooling printing sheet and tinplate can services. The architectural 
design of the strategy that was compiled in order to realize the new industry through 3 stages of strategy, namely strengthening new competencies, strengthening business growth and improving performance (excellence).

\section{REFERENCES}

1. AACSB. (2009). Deploying Professionally Qualified Faculty: An Interpretation of AACSB Standards. Retrieved from http://www.aacsb.edu/ /media/AACSB/Publications/whitepapers/wp-deploying-pq-faculty.ashx.

2. Barnett, R. (2000). University knowledge in an age of supercomplexity. Higher education, 40(4), 409-422. http://dx.doi.org/10.1023/A:1004159513741.

3. Bokor, J. (2012). University of the futures: A thousand year old industry on the cusp of profound change. Australia: Ernst \& Young.

4. Burnes. (2004). Managing Change a strategik approach to organizational dynamics. Harlow: Prentice Hall.

5. David FR.2009.Strategic Management. Ed ke-12. Dodo Sunardi, Penerjemah. Jakarta (ID): Salemba Empat.

6. Dwinanto H.2017.Arsitektur strategic pengembangan bisnis batubara PT $X Y Z$ [tesis].Bogor (ID): Institut Pertanian Bogor.

7. Eko AW.2008. Arsitektur strategik PT Sigma Utama berbasis kompetensi inti [tesis].Bogor (ID): Institut Pertanian Bogor.

8. Hamel G, Prahalad CK. 1994. Competing for the future. Boston (US): Harvard Business School Press.

9. Hamel G, Prahalad CK. 1989. Strategic intent. Harvard Business Review 67 (3):63-76

10. Hunger JD, Wheelen TL.2012.Strategic Management and Business Policy: Toward Global Sustainability. New Jersey (US): Prentice Hall.

11. Hubeis M, Najib M.2008.Manajemen strategik dalam pengembangan daya saing organisasi. Jakarta (ID): PT Elex Media Komputindo.

12. Inayatullah, S., \& Gidley, J. (2000). Trends Transforming the Universities of This Century: Virtualize, Disappear, or Transform. On the Horizon, 8(2), 1-6. http://dx.doi.org/10.1108/10748120010803357.

13. Indonesian Goverment. (2012). Law No. 12 Year 2013 on Higher Education. Jakarta: Sekretariat Negara.

14. Indonesian Goverment. (2013). Indonesian Government Regulation No. 66 Year 2013 on the Statute of Bogor Agricultural University. Jakarta: Sekretariat Negara.

15. Janićijević, N. (2010). Business processes in organizational diagnosis. Management, 15(2), 85-106.

16. Leonard-Barton D.1992.Core capabilities and core rigidities: a paradox in managing new product development.Strategic Management Journal 13:111-125.

17. Ljungquist U.2007.Core competency beyond identification; presentation of a model.Management Decision.45(3): 393-402.

18. Logahan JM, Putri YTE.2013.Pengaruh komunikasi pelayanan and kepuasan terhadap loyalitas pelanggan di 7-eleven Buaran.Binus Business Review 4(2): 886-896.

19. Mohajan HK.2018.An analysis on BCG Growth Sharing Matrix. Noble International Journal of Business and Management. 2(1):01-06.

20. Mulyani N.2002.Tantangan perusahaan di Indonesia dalam menghadapi persaingan global.Jurnal Widya Manajemen and Akuntansi. 2(3):255-269.

21. Nainggolan YT.2011.Arsitektur strategik PT Petrokimia Gresik 2010-2020 [tesis].Bogor (ID): Institut Pertanian Bogor.

22. Nugroho AW.2017.Arsitektur strategik perusahaan pelayaran: studi kasus pada PT Bahtera Adiguna [tesis].Bogor (ID): Institut Pertanian Bogor.

23. Nugroho TT, Najib M, Kirbrandoko.2018.Penentuan daya saing berbasis analisis kompetensi inti (studi kasus pada ekowisata bakau di Jawa Timur).Jurnal Manajemen, Strategi Bisnis and Kewirausahaan. 12(1):25-32.

24. Nykiel, R.2005. Hospitality management strategies. New Jersey (US): Pearson 


\section{Education.}

25. Oktavia E.2017.Arsitektur strategik pada perusahaan perunggasan: studi kasus pada PT Sierad Produce Tbk [tesis].Bogor (ID): Institut Pertanian Bogor.

26. Palmer I, Dunford R, Akin G.2006. Managing Organizational Change: A Multiple Perspective Approach. New York (USA): McGraw-Hill.

27. Papulova Z.2014.The significance vision and mission development for enterprises in Slovak Republic.Journal Of Economics, Business And Management: 2(1):12-16.

28. Pemerintah Republik Indonesia.2009. Undang-undang No.1 Tahun 2009 tentang Penerbangan. Jakarta (ID): Sekretariat Negara.

29. Prahalad CK, Gary H. 1990. The core competence of the corporation. Harvard Business Review 68(3):1-15.

30. Simatupang, T. M. (2013). Business Scientific Paradigmatic Analysis. Seminar on Development of Business Administration Paradigm.

31. Yoshida DT.2001.Arsitektur strategik fasilitator perdagangan berjangka komoditi di Indonesia [tesis].Bogor (ID): Institut Pertanian Bogor.

32. Yoshida DT.2006.Arsitektur Strategik Solusi Meraih Kemenangan Dalam Dunia Yang Senantiasa Berubah. Jakarta (ID): PT Elex Media Komputindo.

33. Yuswohady.2018.Welcome leisure economy [internet].[Diunduh pada 2018 Mei 11]. Tersedia pada https://www.yuswohady.com/2017/10/28/welcome-leisure-economy/.

34. Wheelen, T. L., \& Hunger, J. D. (2012). Strategik Management and Business Policy: Toward Global.

35. Sustainability (13rd ed.). Amerika Serikat: Pearson Education, Inc.

36. Wit, B. D., \& Meyer, R. (2004). Strategy: Process, Content, Context. Italy: Thomshon Learning. 